\title{
Soft money
}

Daniel S. Greenberg

\section{A Fragile Power: Scientists and the State. By Chandra Mukerji. Princeton University Press: 1989. Pp. 253. $\$ 24.95$.}

IT IS late to discover that the cohabitation between science and the US government is loveless and rooted in mutual exploitation. Or that obtaining grants "is hardly guaranteed in the system, and being able to support oneself as a researcher in the United States is not a simple job". Chandra Mukerji, professor of sociology and communication at the University of California, San Diego, has examined one sector of the US scientific enterprise, oceanography, and is dismayed to find a marriage of convenience with the federal government. Although her researches were focused on oceanographers, she claims her findings extend to other sciences, a tenuous proposition given the Navy's consuming interest in the ocean sciences. In any case, the result is what she describes as "a book that many scientists may find offensive because it is designed to attack precisely those areas of science and science policy that polite people have learned to ignore".

The book's weighty bibliography indicates that these areas are far from ignored. Moreover, it is doubtful that many scientists, polite or not, will find this volume offensive, let alone factually eye-opening. More likely, many will find it naive, but possibly also provocative and tantalizing for its fresh, though unfortunately poorly developed, assertions about the nature of relations between US researchers and their government patrons.

Central to Mukerji's thesis is a commonplace underpinning of US research economics, 'soft-money' grants, the scientific version of junk bonds - rewarding but risky. Little explored by other scholars of science policy, soft money is viewed by the author as a cunning mechanism for political management of science. Why do federal research agencies deal in soft money, which is of relatively short duration and uncertain renewability? Because "Soft money scientists constitute a reserve labor force in the sense that they are supported by government and industries so their honed skills will be available when they are needed (by, for instance, the military in case of war, by industry in case there are major changes in the direction of the economy, or by the medical community if there is an outbreak of some new and threatening illness)".

What does government want of these scientists? Based on interviews with oceanography and their federal managers and policy makers, Mukerji states that "government interest in research was not well explained by government need for the information [italics in original] generated by scientific projects. I was led to the conclusion that when government agencies dispense money to scientists for research, they do it not so much because the state is interested in maximizing its store of scientific information relevant to policy issues, but more because the government has interests in maintaining a labor force of skilled scientists available for consultation on policy issues".

In reality, however, relatively few scientists are summoned to consult on policy issues. And of those called, many are financed firmly by industry or academe, or are tenured civil servants, in positions mercifully remote from the perils of soft money. Mukerji does not mention the burdens of the alternative to soft money, the eternal block grant, which arrives even after scientific senescence has set in.

Mukerji contends that "like the unemployed on welfare, scientists on research grants are kept off the streets and in good health because of the interests and investments by elites". They thus comprise a "reserve labor force" for meeting national needs, she says. But she rests this iconoclastic interpretation on the dubious asser-

\section{Spring paperbacks}

- A collection of paperbacks that would be the envy of anyone's holiday suitcase is issued this spring by Penguin. Published today is What Mad Pursuit, Francis Crick's autobiography, reviewed in Nature (336, 268; 1988 ) by John Cairns, price $£ 4.99$. Stephen J. Gould's collection of essays An Urchin in the Storm ranges from topics in geology and evolution to portraits of biologists. In his review (330, 280; 1987), Alan Brafield likened Gould to "his avian namesake the jay, colourful and garrulous". Price is £5.99. Richard P. Feynman' $s$ famous lectures on quantum electrodynamics, $Q E D$, were first reviewed in $1986(320,661)$ by P. Waloschek, who recommended that "anyone with a curiosity about physics today should buy it", price £4.99. Catherine Caufield's book on the "chronicles of the radiation age", Multiple Exposures, is published at $£ 5.99$. John Dunster in his review $(\mathbf{3 4 1}, 30 ; 1989)$ called the book gripping, but biased. But, he said, "books without bias make dull reading". Ian Stewart's explanation for the layman of the mathematics of chaos, Does God Play Dice?, was described by Robert M. May in his review (338, 686; 1989) as "engaging, accurate and accessible to the uninitiated". Price is $£ 6.99$. - Two new paperbacks from Oxford are The Unheeded Cry, by Bernard Rollin, and Martin Gardner's Whys and Wherefores. The former is subtitled Animal Consciousness, Animal Pain and Science, and is part of Oxford's Studies in Bioethics series, price is $£ 6.95$. The second book is the latest collection of Gardner's essays and reviews, subjects including the puzzles in Joyce's Ulysses, the fantasies of Ray Bradbury, Arthur Clarke et al., and computer programs capable of discovering scientific laws. Price is $£ 5.99$. tion that scientists, at least the outstanding ones, command welfare because "Almost any [other] government would welcome and support them". Now, the mandarins of science in the United States have used many rousing ploys to keep the money flowing - cold war, national prestige, economic competitiveness, cultural value - but flight abroad is not seriously in evidence among them.

A Fragile Power is strongest in its analyses of work at sea, particularly the operations of the deep-sea research submersible Alvin. Through interviews and narrative, Mukerji outlines the interplay of military and scientific considerations in deep-sea research, as well as the different interests and rivalries of the scientific disciplines involved. Her analyses of taped conversations from the Alvin's studies of hydrothermal vents provide insights into the processes of scientific observation. And drawing on her studies of scientists at work, she correctly observes, in an unusually succinct passage, that "the government profits from the relative autonomy of scientists because scientists' belief in their own detachment helps give the voice of science the legitimating power that makes science a resource for the state".

But all too often, Mukerji fills space with trite statements, such as "Many research problems that are funded by government organizations are selected for their salience to clear practical problems", and "The government obviously does not want to fund work that is not good". Correct in both cases, and fortunately so.

Some passages are mysteriously dense: "For many younger and journeyman researchers, the time to advise the state is imminent. They do not feel they can preserve the purity of their research careers by seeking exclusively NSF funds. They look to the Department of Defense and the Department of Energy (among others) to make their research lives either possible or easier. They gain what autonomy they can within applied projects (if they care) and use what techniques they can either to keep publishing (and improving their cultural capital as scientists) or to normalize their advisory work (making themselves contented civil servants with jobs they enjoy doing)."

Mukerji states in her preface, "this is not the book I started out to write", explaining that she was diverted on discovering "how much of the life of the laboratory was devoted to generating or justifying research funds". Indeed it is so devoted, and the subject merits continuing examination. Regrettably, this offering will neither inform the cognoscenti of science nor illuminate its practices for outsiders who wish to understand.

Daniel S. Greenberg is editor and publisher of Science \& Government Report, 3736 Kanawha St NW, Washington, DC 20015, USA. 